\title{
Pemindahan Ibukota Negara Indonesia, Perspektif Kebencanaan
}

\author{
Osmar Shalih ${ }^{12}$ \\ 1) Badan Nasional Penanggulangan Bencana (BNPB) \\ ${ }^{2)}$ Amcolabora Institute \\ (Alumni Geografi UI, Angkatan 2008) \\ e-mail korespondensi: osmar.shalih@gmail.com
}

\section{PENDAHULUAN}

Isu pemindahan ibukota dalam beberapa hari terakhir menjadi isu yang hangat dibicarakan. Pemindahan Ibukota Negara Indonesia dari Jakarta ke Kalimantan misalnya, telah digaungkan sejak tahun 1950an era Presiden Soekarno. Namun, setelah 6 (enam) dasawarsa berlalu realisasinya belum juga terwujud. Bahkan Kajian Bappenas (2018) menyatakan Pemindahan Ibu Kota Negara di Indonesia telah menjadi pengalaman dan wacana sejak jaman kolonal Belanda. Pada awal abad 20, Gubernur Jenderal J.P. Graaf van Limburg Strirum (1916 - 1921) membawa gagasan untuk memindahkan Ibukota Hindia Belanda dari Batavia ke Bandung. Gagasannya didasarkan kepada hasil studi dari H.F. Tillema, ahli kesehatan Belanda kelahiran Groningen yang bertugas di Semarang, tentang kesehatan kota-kota di pesisir utara Jawa. Disimpulkan bahwa kota-kota di pantai utara Jawa tidak sehat untuk dijadikan sebagai kedudukan Kantor Pemerintahan, niaga, industri, pendidikan dan lain-lain [1]. Gagasan pemindahan Ibukota Negara Indonesia tahun 2019 oleh Bapak Presiden Joko Widodo kembali dilontarkan. Lalu dimana lokasi yang tepat menjadi "new" Ibukota Negara Indonesia?

Pertimbangan dalam memindahkan Ibukota Negara antara lain aspek geopolitik, geostrategis, ekonomi, sosial, budaya, sejarah dan faktor lainnya. Belajar dari banyak pengalaman negara lain dalam menentukan lokasi pusat pemerintahannya, terdapat beberapa faktor yang menjadi pertimbangan dalam pemilihan lokasi lbukota Negara. Dari berbagai literatur mengenai pemindahan Ibukota Negara, terdapat beberapa elemen penting dalam pemilihan lokasi, diantaranya elemen: (1) kebencanaan; (2) fisik lingkungan; (3) spasial (kondisi geografis); (4) pertahanan dan keamanan; (5) geopolitik; (6) infrastruktur dasar dan konektivitas antarwilayah eksisting; (7) integrasi sosiokultural; (8) status hukum dan kebijakan (negara); (9) ekonomi wilayah; (10) pemerintah dan aparatur; (11) hubungan internasional dan konstelasi politik; (12) Penguasaan lahan eksisting; (13) skema dan kebutuhan pendanaan; (14) subjektifitas pemimpin. Namun, pada paper ini hanya terfokus pada kajian pemindahan Ibukota Negara Indonesia dengan tinjauan perspektif kebencanaan. 


\section{PEMINDAHAN IBUKOTA (TINJAUAN PERSPEKTIF KEBENCANAAN)}

Pemerintah semakin serius untuk memindahkan pusat pemerintahan dari Jakarta ke wilayah di luar pulau Jawa. Sudah ada 2 (dua) wilayah yang dikunjungi sebagai calon ibu kota baru yakni Palangkaraya (Kalimantan Tengah) dan Bukit Soeharto (Kalimantan Timur) pada bulan Mei 2019 oleh Presiden Joko Widodo dan jajarannya.

Yang menarik, dari kunjungan tersebut adalah belum banyak digalinya aspek kebencanaan. Memang dari aspek bencana Gempa, kedua wilayah tersebut relatif jarang terjadi gempa [2].

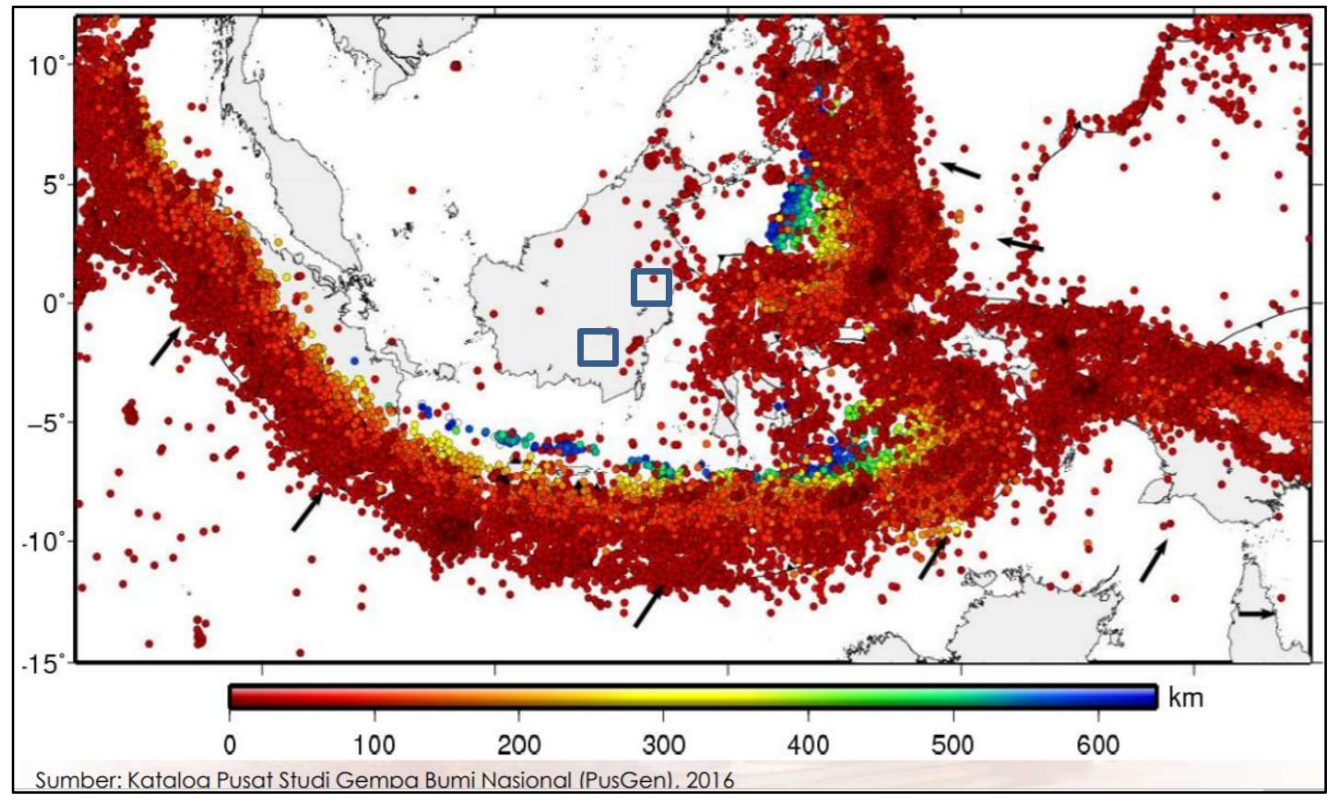

Sumber: Kementerian PPN/Bappenas (2019)

\section{Gambar 1 Katalog Pusat Gempa Bumi Nasional (Pusgen, 2016)}

\section{Hasil Kunjungan Lapangan Provinsi Kalimantan Tengah}

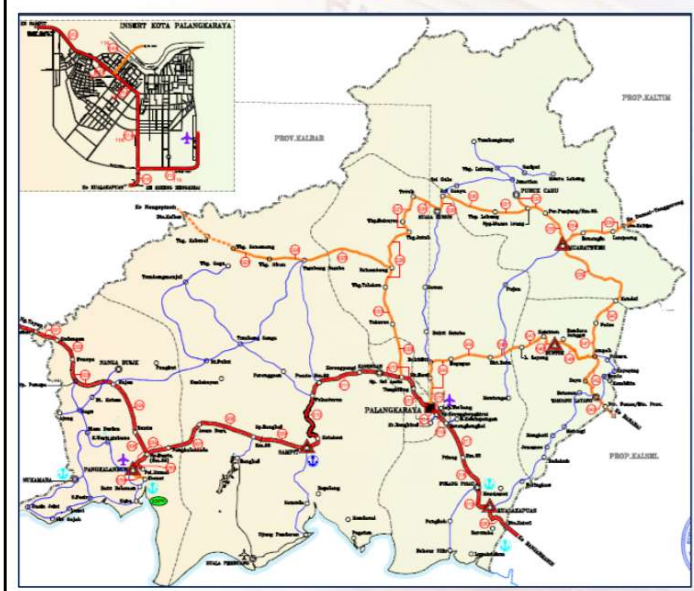

Keunggulan

- Memiliki akses terhadap Bandara Tjilik Riwut (Hierarki Pengumpul Tersier)

Bebas bencana gempa bumi

97,04\% wilayah deliniasi tergolong ke dalam area yang aman dari banjir

Tidak berbatasan langsung dengan batas negara Ketersediaan lahan yang luas dengan $70 \%$ status hutan produksi konversi (bebas konsesi) dan hutan produksi dengan konsesi Hutan Alam

\section{Kelemahan}

- Lokasi jauh dari pelabuhan laut sekitar +6 jam

Ketersediaan sumber daya air tanah terbatas, hanya tersedia air sungai

- Di sebagian besar wilayah deliniasi memiliki lapisan gambut yang rentan terhadap kebakaran hutan dan lahan

Struktur demografi relatif homogen

Sumber: Paparan Menteri PPN/Bappenas (2019)

\section{Gambar 2 Hasil Kunjungan Lapangan Provinsi Kalimantan Tengah}




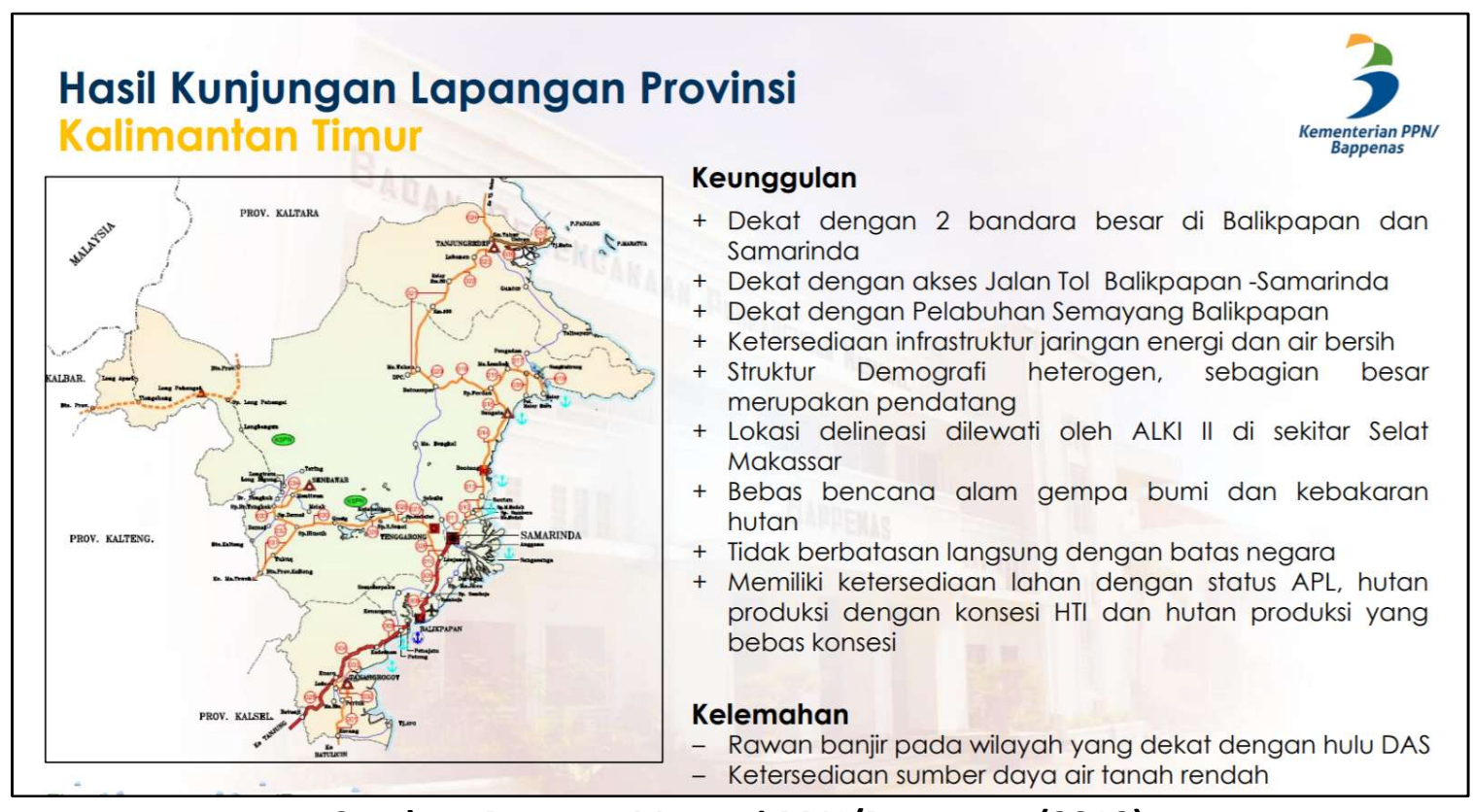

Sumber: Paparan Menteri PPN/Bappenas (2019)

\section{Gambar 3 Hasil Kunjungan Lapangan Provinsi Kalimantan Timur}

Namun dari hasil paparan Menteri PPN/Bappenas (2019), kedua wilayah tersebut tidak terlepas dari bencana "non geologi", antara lain banjir (calon lokasi di Kalimantan Timur) dan Kebakaran Hutan dan Lahan (calon lokasi di Kalimantan Tengah) [2].

Artinya, kedua calon lokasi tersebut potensial bencana jika tidak dikelola dengan baik. Pesan yang ingin disampaikan penulis adalah perlu kehati-hatian dalam menyusun narasi calon lokasi Ibukota Indonesia "aman terhadap bencana". Dalam konteks ini dikarenakan baik pemerintah, pakar, dan media berperan besar dalam membangun kesadaran spasial masyarakat. Perlu narasi yang clear dan proporsional sesuai dengan realita dilapangan agar masyarakat siap dan tangguh (resilience) dalam menghadapi berbagai jenis bencana (multihazard) sesuai karakteristik wilayah masing-masing. Hal ini dikarenakan masyarakat merupakan aktor penting dalam penanggulangan bencana.

Penulis menyoroti bahwa banyak penyusun kebijakan hanya berfokus pada bencana gempa bumi, letusan gunung api dan banjir dalam memutuskan kandidat lokasi yang baru. Perspektif tersebut hanya bertumpu pada ancaman bahaya yang ada di Pulau Jawa (Jawa Sentris). Namun, jika ditelaah lebih lanjut, jenis ancaman bencana di luar Pulau Jawa, maka kebakaran hutan dan lahan merupakan bencana yang memiliki dampak yang relatif besar. Dalam kurun waktu 3-5 tahun secara berulang, El Nino Southern Oscillation (ENSO) terjadi dan memberikan dampak kemarau yang panjang. Jika hal tersebut terjadi, maka tidak menutup kemungkinan kebakaran hutan dan lahan besar terjadi. Kita pernah mengalami hal tersebut dalam beberapa kurun waktu terakhir, dimana akses penerbangan pesawat di beberapa kota besar di Indonesia terganggu akibat tebalnya kabut asap dari kebakaran hutan dan lahan. Tidak hanya di Indonesia saja yang merugi, tetapi negara tetangga pun terkena imbasnya. Kebakaran hutan dan lahan tidak hanya terjadi pada kawasan hutan, namun dapat terjadi pada area lahan gambut. Ketika kebakaran terjadi di area lahan gambut, maka kebakaran hutan dan lahan relatif akan sulit untuk dikendalikan. Jikalau Pemerintah akan memilih lokasi antara kedua wilayah tersebut, yaitu Palangkaraya (Kalimantan Tengah) dan Bukit Soeharto (Kalimantan Timur) maka upaya mitigasi dan pengurangan risiko bencana kebakaran hutan dan lahan harus menjadi prioritas. Hampir tidak mungkin rasanya, 
sebuah Ibukota Negara terputus aksesnya dikarenakan bencana kebakaran hutan dan lahan. Sebab Ibukota negara tentunya, akan mencerminkan jati diri dan identitas bangsa. Jikalau pemerintah tidak siap melakukan mitigasi dan pengurangan risiko bencana kebakaran hutan dan lahan, maka hal ini akan berdampak buruk bagi citra negara Indonesia dikancah internasional.

Kita bisa belajar dari Myanmar untuk pemindahan Ibukota dalam konteks pemahaman risiko bencana. Kota Yangon, ibu kota terdahulu, rentan terhadap bencana angin puting beliung. Naypyidaw terletak $370 \mathrm{~km}$ dari Yangon, dan relatif lebih aman dari ancaman bahaya puting beliung. Artinya, aspek kebencanaan bisa menjadi faktor pendorong untuk pemindahan lbukota, namun juga menjadi pertimbangan dalam penetapan calon lokasi Ibukota. Pendekatan multi hazard risk harus terintegrasi dalam perencanaan kedepan dalam menetapkan lokasi ibu kota negara. Dengan pemahaman dan kesadaran spasial multi hazard risk sejak dini, maka investasi membangun ibu kota negara, niscaya akan lebih murah. Mainstreaming pengurangan risiko bencana harus menjadi bagian yang tak terpisahkan dalam perencanaan spasial pemindahan ibukota.

Namun sebetulnya, dimana lokasi di Indonesia yang aman terhadap bencana? Berdasarkan data BNPB melalui akses Inarisk BNPB (2019), dengan pendekatan Provinsi dan Kabupaten/Kota, maka semua wilayah di Indonesia berisiko sedang sampai dengan tinggi [3].

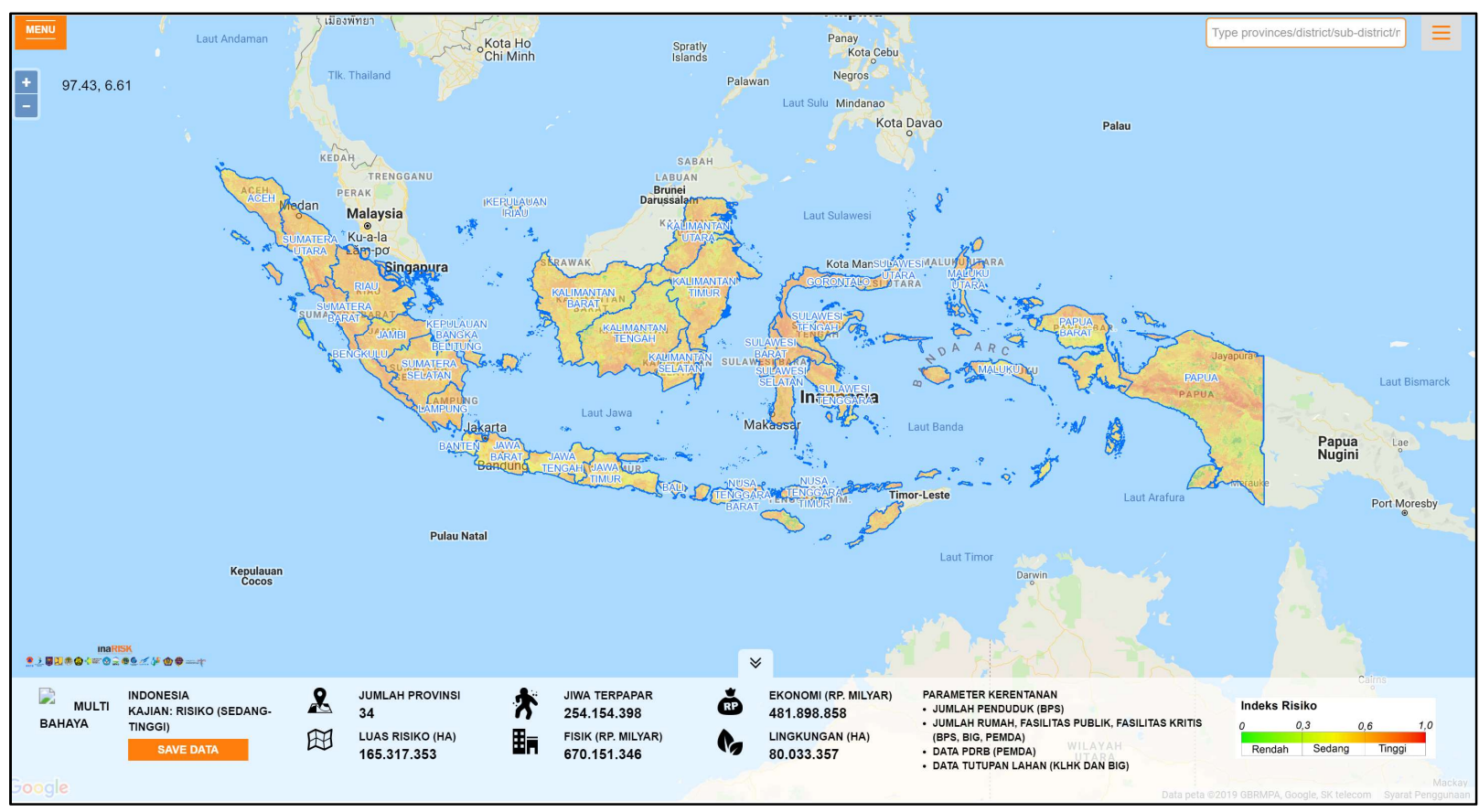

Sumber: http://inarisk.bnpb.go.id/ (2019)

Gambar 4 Kajian Risiko Bahaya Indonesia 


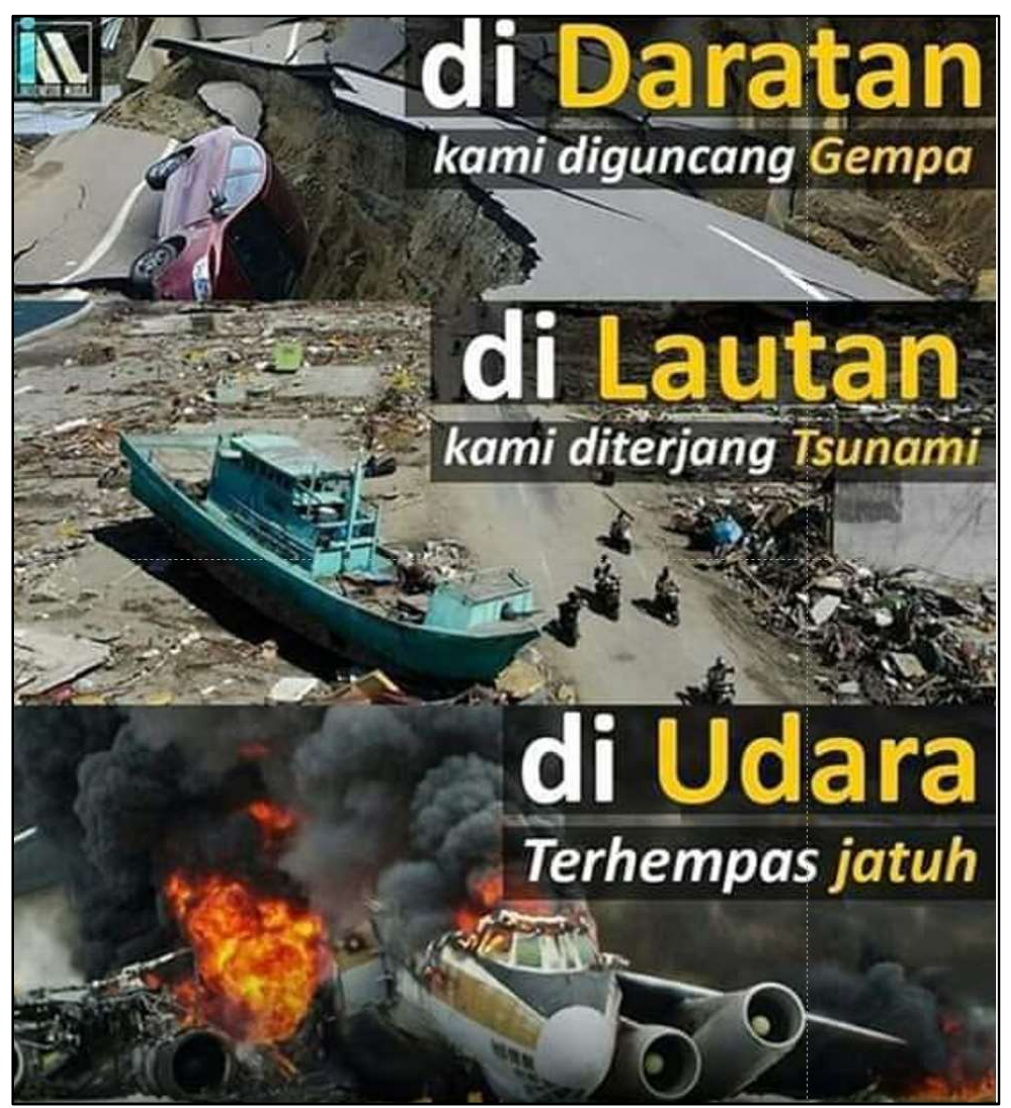

Sumber: Karsidi (2019)

\section{Gambar 5 "Di darat di guncang gempa, di laut diterjang tsunami, di udara terhempas jatuh"}

Untuk mengantar pada bagian akhir, penulis menyampaikan bahwa tidak ada lokasi yang aman sepenuhnya dari ancaman bencana di Indonesia. Oleh karenanya, yang paling penting adalah meningkatkan ketahanan individu, komunitas, dan wilayah dalam menghadapi bencana. Ketahanan bencana yang dimaksud adalah meningkatkan (1) kapasitas untuk mengurangi risiko atau kerusakan melalui mitigasi dan adaptasi; (2) kapasitas untuk mempertahankan fungsi-fungsi dasar dan struktur di dalam keadaan bencana, dan (3) kapasitas untuk memulihkan diri dari pasca kejadian bencana [5d].

Pertimbangan adanya potensi ancaman bencana dalam membangun sebuah kota memang sangat krusial. Namun yang tidak kalah penting adalah membangun ketahanan (resiliensi) bencana. Jepang merupakan lesson learn yang baik dalam hal pengintegrasian perencanaan spasial, implementasi pembangunan dan membangun ketahanan bencana. Infrastruktur yang dibangun tidak hanya fisik yang tahan bencana, tetapi juga manusianya yang tangguh bencana.

Harapan penulis, kebijakan pemindahan ibu kota ini direncanakan dengan baik dan matang, tidak hanya satu aspek saja, tetapi multi aspek. Tidak cukup dengan menggunakan asumsi-asumsi yang dibangun tanpa dasar tetapi kembali pada hakikat tujuan awalnya untuk apa dan siapa pembangunan di Indonesia? Tentunya, untuk sebesar-besarnya kemakmuran seluruh rakyat Indonesia. 


\section{Penutup}

Perencanaan spasial pemindahan ibukota negara penting untuk memperhatikan multi hazard risks. Namun, yang tidak kalah penting adalah membangun ketahanan (resiliensi) individu,komunitas, dan wilayah dalam menghadapi ancaman bencana.

\section{DAFTAR PUSTAKA}

[1] Kementerian PPN/Bappenas. (2017). Penyusunan Konsep Pemindahan Ibu Kota Negara. Jakarta, Indonesia.

[2] Kementerian PPN/Bappenas. (2019). Pemindahan Ibu Kota Negara dalam Dialog Nasional Pemindahan Ibukota Negara 16 Mei 2019. Jakarta, Indonesia.

[3] Badan Nasional Penanggulangan Bencana. (2019). Indeks Risiko Bencana Indonesia. http://inarisk.bnpb.go.id/, diakses pada tanggal 30 Mei 2019.

[4] A, Karsidi (2019). Bahan Ajar Mata Kuliah Ketahanan Wilayah Terhadap Perubahan Iklim. Magister Ilmu Geografi Universitas Indonesia. Depok, Indonesia.

[5] Characteristics of a Disaster-resilient Community A Guidance Note Characteristics of a Disaster-resilient Community: A Guidance Note. Version 1. John Twigg for the DFID Disaster Risk Reduction Interagency Coordination Group, 2007. 
W.

3.

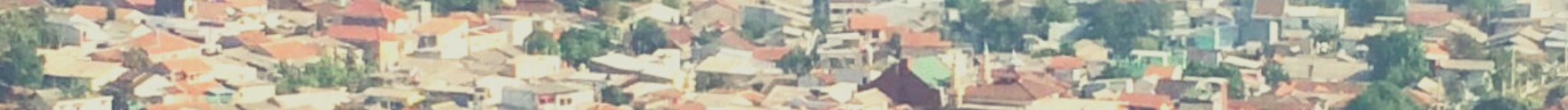

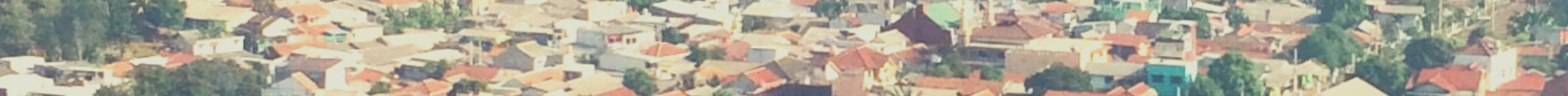

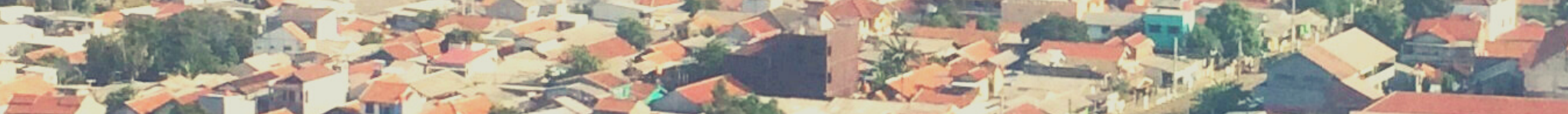

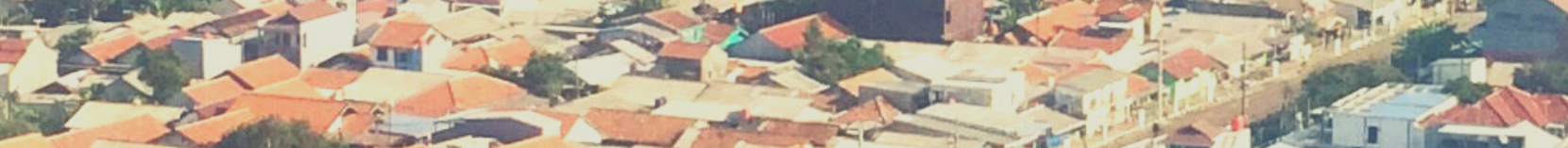

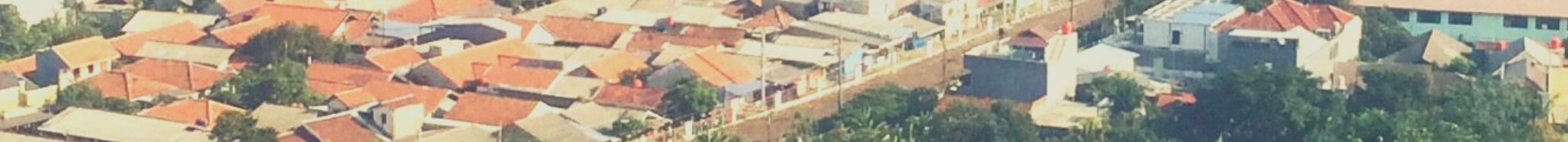

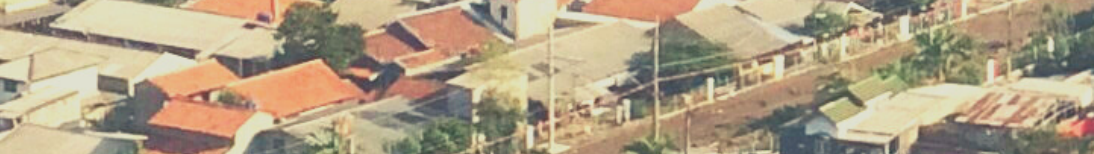

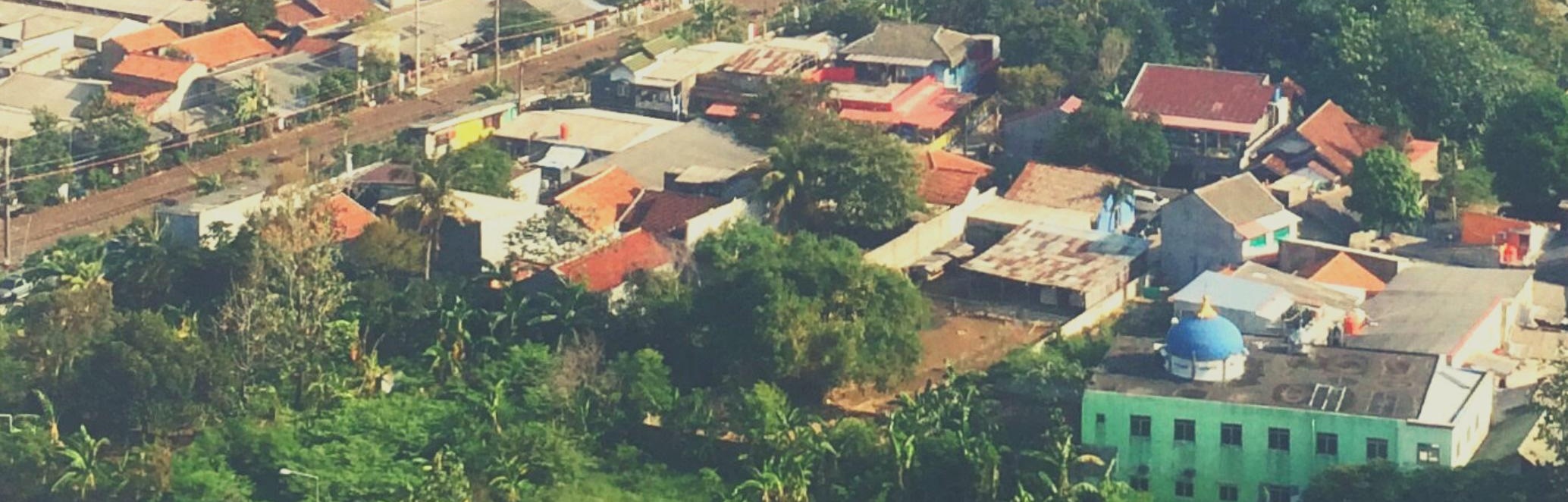
27

\section{- 5}

a $3=-3 \pi$ 


\section{APLIKASI SPASIAL UNTUK PEMBANGUNAN}

Editor

Nurul Sri Rahatiningtyas

Fathia Hashilah

Departemen Geografi

Fakultas Matematika dan IImu Pengetahuan Alam Universitas Indonesia

2019 


\section{APLIKASI SPASIAL UNTUK PEMBANGUNAN}

Penanggung Jawab

Penulis

Editor

Foto \& Design Cover
: Ketua Departemen Geografi Fakultas Matematika dan Ilmu Pengetahuan Alam Universitas Indonesia

: 1. Abdul Rouf

2. Adipandang Yudono

3. Chotib

4. Fajar Dwi Pamungkas

5. Hafid Setiadi

6. Hamid

7. Nurul Sri Rahatiningtyas

8. Nuzul Achjar

9. Osmar Shalih

10. Ratna Saraswati

: 1. Nurul Sri Rahatiningtyas

2. Fathia Hashilah

ISBN: 978-623-92282-1-7

Hak Cipta dilindungi Undang-undang

Copyright@2019

Diterbitkan Oleh:

Departemen Geografi

Fakultas Matematika dan IImu Pengetahuan Alam

Universitas Indonesia

Gedung H Fakultas Matematika dan IImu Pengetahuan Alam Universitas Indonesia Kampus UI Depok. Jawa Barat 16424 


\section{PENGANTAR REDAKSI}

Puji syukur dipanjatkan atas bimbingan Allah SWT hingga dapat diselesaikannya buku "Aplikasi Spasial untuk Pembangunan" ini. Bab-bab yang tercatat dalam buku ini merupakan buah pikir dari sepuluh orang alumni Departemen Geografi FMIPA Universitas Indonesia. Buku ini diharapkan dapat menjadi salah satu sumbangan pemikiran dari Geografi UI untuk Indonesia dalam rangka memperingati ulang tahun ke-60 Departemen Geografi FMIPA UI.

Buku ini berisi delapan bab yang diantaranya membahas mengenai pengembangan infrastruktur sosial ekonomi wilayah, infrastruktur data spasial nasional, pemodelan spasial, aplikasi spasial di wilayah pesisir, ruang ekologis dan pembangunan berkelanjutan, kawasan ekonomi dan industri terpadu, dan perspektif kebencanaan untuk pemindahan ibukota negara Indonesia.

Besar harapan kami tulisan-tulisan ini dapat menjadi inspirasi semua pihak. Dan khususnya dapat bermanfaat langsung dalam proses pembangunan di Indonesia. Kami ucapkan terima kasih atas partisipasi para alumni dan Departemen Geografi FMIPA UI yang telah mendukung terselenggaranya buku ini.

Depok, November 2019

Editor 


\section{DAFTAR ISI}

Pengantar Redaksi lii

Daftar Isi iv

Pengembangan Infrastruktur Sosial Ekonomi Wilayah (PISEW) 1-8

Abdul Rouf

Apakah Integrasi Infrastruktur Data Spasial Nasional (IDSN) dan Volunteered

Geographic Information (VGI) Sebagai Solusi dalam Gap Pengelolaan Informasi Geospasial di Indonesia?

Adipandang Yudono

Spatial Lag dan Spatial Error: Solusi Masalah Heteroskedastisitas dalam

Pemodelan Spasial

Chotib

Aplikasi Spasial untuk Pembangunan Wilayah Pesisir (Studi Kasus: Delta Ci

Manuk bagian Timur)

Fajar Dwi Pamungkas, Ratna Saraswati

Pembangunan Wilayah: Gagasan Ruang Ekologis dan Pembangunan

$35-43$

Berkelanjutan

Hafid Setiadi, Nurul Sri Rahatiningtyas

Kawasan Ekonomi dan Industri Terpadu Bekapur (Potensi, Permasalahan, dan

Penataan)

Hamid

Analisis Pola dan Konsentrasi Spasial Sektor Industri Manufaktur di Provinsi

$54-64$

Banten 2010-2018

Nuzul Achjar

Pemindahan Ibukota Negara Indonesia, Perspektif Kebencanaan

$65-70$

Osmar Shalih 


\section{SEJARAH DEPARTEMEN GEOGRAFI FMIPA UI}

Pendirian Jurusan Geografi FMIPA UI dipelopori TNI Angkatan Darat, yang dilatarbelakangi oleh keinginan untuk menyediakan tenaga-tenaga ahli dalam pembuatan peta dan analisis peta bagi keperluan militer. Sejak diresmikan pada tanggal 27 November 1959, segala aktivitas perkuliahan diadakan di Gedung Lembaga Geografi, Jawatan Topografi (Jantop) TNIAD yang berlokasi di Jl. Dr. Wahidin no. 11, Gunung Sahari, Jakarta Pusat. Sampai dengan tahun 1966, Jurusan Geografi berada di bawah Fakultas IImu Pasti dan Alam, Universitas Padjadjaran (FIPIA-Unpad) di Bandung. Melalui Surat Keputusan Direktur Jenderal Pendidikan Tinggi Depdikbud no. 79 tanggal 08 Oktober 1966, Jurusan Geografi berada dibawah pengelolaan Fakultas Matematika dan Ilmu Pengetahuan Alam, Universitas Indonesia (FMIPAUI). Sejak tahun 1970, perkuliahan di Jurusan Geografi dipindahkan ke Kampus UI di Salemba. Pada tahun 1987, perkuliahan dan administrasi pendidikan dipindahkan ke Kampus UI di Depok sampai saat ini.

Tahun 1995, bekerjasama dengan Direktorat TISDA Badan Pengkajian dan Penerapan Teknologi (BPPT), Jurusan Geografi mendirikan Pusat Penelitian Geografi Terapan (PPGT) atau Center for Applied Geography Research. Pusat ini telah berhasil melakasanakan kegiatan penelitian, pelatihan dan pelayanan pada masyarakat. Kegiatan tersebut diselenggarakan melalui kerjasama dengan badan pemerintahan, perusahaan swasta dan juga beberapa lembaga internasional. Pada Tahun 1998, Jurusan Geografi mendirikan Program Pascasarjana Geografi yang menawarkan Program Magister (S2) Ilmu Geografi.

Terhitung mulai tanggal 01 Januari 2000 Jurusan Geografi menempati gedung baru berlantai 4, yaitu Gedung H FMIPA UI, yang dibangun dengan dana pemerintah. Pada tahun yang sama seiring dengan dengan pemberian status BHMN pada Universitas Indonesia (PP No. 152 Tahun 2000 tanggal 26 Desember), Jurusan Geografi diubah namanya menjadi Departemen Geografi. Saat ini Departemen Geografi semakin dituntut untuk memberikan kontribusi nyata bagi masyarakat terutama melalui penerapan ilmu pengetahuan dan teknologi serta penyediaan sumber daya manusia yang berkualitas. Akreditasi terakhir dari Badan Akreditasi Perguruan Tinggi (BAN-PT) Kementerian Pendidikan dan Kebudayaan, baik untuk Departemen S1 maupun Program S2 diperoleh peringat akreditas A (Baik Sekali), dan dinyatakan dengan surat keputusan dengan Nomor:042/BAN-PT/Ak-XVI/S1/ X1/2012 untuk program S1 dan Nomor: 284/SK/BANPT/Ak-XI/XII/2013 untuk progam S2. Akreditasi ini berlaku untuk jangka waktu 5 tahun.

Hingga tahun 2019, Program Sarjana Geografi tercatat telah menghasilkan lebih dari 2000 sarjana. Sementara Program Magister Ilmu Geografi sejak berdiri tahun 1998 telah menghasilkan lebih dari 300 magister. Para lulusan bekerja baik sebagai pegawai pemerintahan, swasta maupun bekerja secara mandiri. Di pemerintahan, para lulusan banyak bekerja di Kementrian Agraria dan Tata Ruang, Kementrian Pekerjaan Umum dan Perumahan, Kementerian Lingkungan Hidup dan Kehutanan, Kementerian Riset dan Pendidikan Tinggi, Kementerian Kelautan dan Perikanan, Badan Informasi Geospasial, Badan Meteorologi, Klimatologi dan Geofisika. Kementerian Pertahanan, Badan Nasional Penanggulangan Bencana (BNPB), Bappenas, dan lainnya. Sementara di swasta, lulusan geografi banyak bekerja di Perusahaan Perkebunan, Pertambangan, Survei dan Pemetaan, Sistim Informasi, dan bamyak lagi perusahaan-perusahaan yang membutuhkan tenaga ahli Sistem Informasi Geografis. 